Gothic Subjects 



\title{
Gothic Subjects
}

\author{
The Transformation of Individualism \\ in American Fiction, 1790-186I
}

\section{Siân Silyn Roberts}

\author{
$\overline{\text { PENN }}$ \\ UNIVERSITY OF PENNSYLVANIA PRESS \\ PHILADELPHIA
}


Copyright (C) 2014 University of Pennsylvania Press

All rights reserved. Except for brief quotations used for purposes of review or scholarly citation, none of this book may be reproduced in any form by any means without written permission from the publisher.

$$
\begin{gathered}
\text { Published by } \\
\text { University of Pennsylvania Press } \\
\text { Philadelphia, Pennsylvania I9IO4-4II2 } \\
\text { www.upenn.edu/pennpress }
\end{gathered}
$$

Printed in the United States of America on acid-free paper IO 987765432 I

Library of Congress Cataloging-in-Publication Data Silyn Roberts, Siân.

Gothic subjects: the transformation of individualism in American fiction, 1790-I86I / Siân Silyn Roberts. — Ist ed.

$$
\text { p. } \mathrm{cm} \text {. }
$$

Includes bibliographical references and index.

ISBN 978-0-8I22-46I3-I (hardcover : alk. paper)

I. Gothic fiction (Literary genre), American-History and criticism. 2. American fiction-19th centuryHistory and criticism. 3. Individualism in literature. 4. Enlightenment-Influence. 5. National characteristics, American, in literature. I. Title.

$\mathrm{PS}_{374 . G 68 S} 5720 \mathrm{I} 4$

813'.0872909-dc23 
To Matthew and my family, with love 
